Marklund H., Rollnik-Sadowska E., The role of private companies in the Danish active labour market policy, „Ekonomia i Prawo. Economics and Law”, Polszakiewicz B., Boehlke J. (ed.), Vol. 15, No. 2/2016, pp. 209-218. DOI: http://dx.doi.org/10.12775/EiP.2016.013.

\author{
Hanne Marklund", EWA Rollnik-Sadowska*
}

\title{
THE ROLE OF PRIVATE COMPANIES IN THE DANISH ACTIVE LABOUR MARKET POLICY
}

\author{
SUMMARY
}

In this paper the authors present a new, extended approach, involving collaboration strategies between public employment services and private companies, which were under implementation in 2015 in Aarhus (Denmark). The main thesis of the paper is that the cooperation of public labour market institutions with labour demand representaives is crucial in realisation of active labour market policy. The Danish labour market policy is based on the flexicurity model that combines the flexibility of employment assisted by employment security assured by both, developed active labour market programmes and a rationalized system of benefits. The authors also propose some reccommendations for Poland in the area of boosting cooperation between public employment services and business representatives following the Danish example.

The research method was the analysis of secondary data, such as literature overview, as well as strategies and reports made on behalf of the Jobcenter Aarhus.

Keywords: active labour market policy; Danish flexicurity model; labour demand approach

JEL Classification: J08; J68; J88; H53

" Hanne Marklund, Jobcenter Aarhus, Employment Department, Værkmestergade 15, 8000 Aarhus C, Denmark, phone: +45 515763 34, e-mail: hmar@aarhus.dk.

"'Ewa Rollnik-Sadowska, Bialystok University of Technology, Faculty of Management, Dapartment of Economics and Social Sciences, ul. O. Tarasiuka 2, 16-001 Kleosin, Poland, phone: +48 660759 656, e-mail: e.rollnik@pb.edu.pl (corresponding author).

$\checkmark$ The article was funded by Faculty of Management, Bialystok University of Technology (S/ WZ/4/2015). 


\section{INTRODUCTION}

The efficiency of labour market policy is increasing one of the main objectives of economic policy as it influences the rationalization of usage of public expenditures as well as the improvement of employability of human resources.

Denmark is an example of a country, which has introduced several phases of labour market reforms regarded as model rules for the other EU countries. The Danish public authorities on regional levels are continuously searching for new solutions, which assure a higher efficiency of the labour market model by meeting the needs of different social partners.

As a result, labour market indicators in Denmark are stable and they have reached a better position in comparison to the majority of EU countries. In 2014 the rate of unemployment was much lower than the EU-27 average of $10.2 \%$, reaching $6.6 \%$. Moreover, the employment rate in Denmark has for many years exceeded 75\%, and in 2014 it reached a level of $75.9 \%{ }^{1}$. Simultaneously, Denmark represents one of the EU countries with the highest share of GDP spent on public expenditures on labour market policies (in 2012 it was $3.676 \%$ of GDP) ${ }^{2}$.

Denmark is mainly known for the implementation of the flexicurity mod$\mathrm{el}$, which is a combination of numerical flexibility (owing to low employment protection legislation), social security (in the form of a generous system of unemployment benefits), and active labour market policies especially focused on active job search and training ${ }^{3}$. According to the flexicurity hypothesis, flexibility and security are not contradictions, but may be mutually supportive if the appropriate labour market institutions are in place ${ }^{4}$.

${ }^{1}$ Next to Denmark, the indicator also exceeds $75.0 \%$ in Sweden (80.0\%), Germany $(77.7 \%)$, the United Kingdom (76.2\%) and the Netherlands (75.4\%) (Eurostat, Database, http:// ec.europa.eu/eurostat/data/database (14.09.2015)).

${ }^{2}$ In this area, Denmark occupies the second position in the EU - the first being Spain with an indicator of $3.701 \%$ of GDP spent on public expenditures on labour market policies. The Spanish rate is resultant of the country's rather difficult labour market situation and the significant need of implementation prevention actions (since 2009 it has seen a substantial growth of GDP share spent on labour market policies) (Eurostat, Database, http://ec.europa. eu/eurostat/data/database (14.09.2015)).

${ }^{3}$ E. Rollnik-Sadowska, System welfare state w Danii - gtówne zatożenia, "Ekonomia i Zarządzanie", Vol. 5, No. 2/2013, pp. 18-19 .

${ }^{4}$ K. Madsen, The Danish model of "flexicurity" - a paradise with some snakes, [in:] H. Sarfati, G. Bonoli (eds.), Labour market and social protection reforms in international perspective. Parallel or converging tracks?, Ashgate/ISSA, Aldershot 2002, pp. 243-265. 
In Denmark, the networking between social partners - public authorities, employer organisations, employee organisations (trade unions) is crucial to achieve the efficiency of a labour market policy. In effect, Denmark, in as much as the rest of the Nordic countries, represents cooperative labour relations and a high-union density, leading to low-state regulations ${ }^{5}$.

The paper's objective is to present the Danish collaboration model between public labour market institutions and private companies as well as looking for possibilities of implementing that model within Polish conditions. The main thesis of the paper is that the cooperation of public labour market institutions with labour demand representaives is crucial in realisation of active labour market policy.

The undertaken research method was the analysis of secondary data as a literature overview, as well as strategies and reports prepared on behalf of the Jobcenter Aarhus.

\section{LABOUR MARKET POLICY IN DEMARK — LITERATURE OVERVIEW}

Denmark belongs to the Nordic labour market model with a high level of both, union membership and collective bargaining coverage. Employment conditions and wages have largely been settled by collective agreements. There are comparatively few formal legislative rules regulating the labour market.

Denmark was the initiator of the flexicurity policy in the 90 's of the $20^{\text {th }}$ century, which consists of three components - a flexible labour market (external numerical flexibility), an active labour market policy and a generous social security system. The Danish type of flexicurity works as a kind of unwritten contract, or as a historical compromise between the state, the employers and the employees (trade unions). Without the approval of all three parties the flexicurity policy would not work. This model has been adopted by the rest of the Nordic countries and the Netherlands. Nowadays its implementation is recommended by other countries of the European Union under "the Agenda for New Skills and Jobs", which is part of the Europe 2020 strategy for smart, sustainable and inclusive society growth ${ }^{6}$.

${ }^{5}$ W. Salverda, D. Checchi, Chapter 18 - Labor Market Institutions and the Dispersion of Wage Earnings, "Handbook of Income Distribution", Vol. 2/2015, p. 1603.

${ }^{6}$ E. Rollnik-Sadowska, Transformation of European Labour Market Policy Models Exemplified by Denmark, Germany and The United Kingdom, "Optimum. Studia Ekonomiczne", No.5(71)/2014, p. 44. 
From the policy maker's point of view, the studies prove that flexibility can be obtained without detrimental effects to workers' satisfaction, if policies aimed at favouring the use of flexible contracts are coupled with policies aimed at enhancing employment stability, such as active labour market policies in order to assist workers in their transition from one job to another ${ }^{7}$. From a company point of view, the model provides a flexible work force while from the wage earners' view the model includes a safety net. The system is financed by the state to a large extent.

Labour market reforms started in Denmark in 1994 seeking to shift the focus from a rather passive labour market policy to a more active one. The policy tightened eligibility and duration of unemployment benefits and introduced workfare elements into social policy, thus a more activating approach was adopted ${ }^{8}$. Subsequent changes were aimed at strengthening active labour market measures on the principle that benefit entitlements should be conditional on participation in active labour market programmes (the "right and duty" principle) $)^{9}$. As a result, a large-scale enrolment of the unemployed into programmes has occurred, following that the Danish system of active labour market programs (ALMPs) is one of the most extensive in the OECD.

The studies measuring costs and benefits of the Danish ALMPs prove that private job training programmes have substantial positive employment and earnings effects, in as much as public job training results in positive earnings effects. Classroom training does not significantly improve employment or earnings prospects in the long run. When costs are taken into account, private and public job training still emerge with surpluses, while classroom training tends to lead to deficit programmes ${ }^{10}$.

Studies of Rosholm and Svarer show also positive impact of the mandatory interviews at the jobcenters and the sanctions, depriving the unemployed the benefit aid if they do not participate in assigned work. Those instruments influence on getting the unemployed back into employment ${ }^{11}$.

Typically characteristic for the Danish labour market is that labour market institutions play an important role in implementing labour market pol-

${ }^{7}$ F. Origo, L. Pagani, Flexicurity and job satisfaction in Europe: The importance of perceived and actual job stability for well-being at work, "Labour Economics", Vol. 16, No. 5/2009, p. 554.

8 T.M. Andersen, M. Svarer, Flexicurity Labour Market Performance in Denmark, "CESifo Economic Studies", Vol. 53, No. 3/2007, p. 391.

9 S.T. Jespersen, J.R. Munch, L. Skipper, Costs and benefits of Danish active labour market programmes, "Labour Economics", Vol. 15, No. 5/2008, pp. 862-863.

${ }^{10}$ Ibidem, p. 860.

${ }_{11}$ M. Rosholm, M. Svarer, Overordnede effekter af aktiv arbejdsmarkedspolitik, http://star.dk (09.04.2016). 
icies, and many labour market reforms are the outcome of tripartite agreements between unions, employer confederations and the government. This is also true for the above mentioned labour market reforms of the 1990s, that introduced active labour market measures to the unemployed on a larger scale ${ }^{12}$.

One of the objectives of the Danish labour market policy, over and above an increase in employability is the social integration of ALMP beneficiaries. It would be impossible to reach without the cooperation of the various social partners and public authorities. The tradition of cooperation is present among social partners in Denmark since the late nineteenth century. This dialogue includes the government, social partners and policy communities at a regional leve ${ }^{13}$. Governments in Denmark need this dialogue because they generally represent a coalition between minority partners, having to find support from different social groups ${ }^{14}$.

\section{COOPERATION MODEL OF DANISH JOBCENTERS AND PRIVATE COMPANIES — EXAMPLE OF AARHUS MUNICIPALITY}

The efficient management of the labour market is a crucial issue. It is more important than ever to assist the labour force with their potential and the acquisition of lifetime skills. The demand for skills will need to be enhanced by helping companies raise productivity. These tasks require intensive actions on the local level.

There is an extended focus on the collaboration with private companies in the Danish employment efforts. That collaboration can be understood as both, activation of the unemployed and their recruitment. An important concept for activation is that the unemployed are placed in companies and then trained in these companies in order to train and educate applicants for the present labour demand of a particular company. The training thus takes place at a prospective workplace and is in close cooperation with the company and the unemployed person ${ }^{15}$.

12 T. Jespersen, J.R. Munch, L. Skipper, op. cit., p. 860.

${ }^{13}$ W. Ochel, The Political Economy of Two-Tier Reforms of Employment Protection in Europe, “CESifo Working Paper”, No. 2461/2008, p. 13.

${ }^{14}$ F. Larsen, The Importance of Institutional Regimes for Active Labour Market Policies: The Case of Denmark, "European Journal of Social Security", Vol. 6, No. 2/2004, pp. 137-154.

${ }_{15}$ KL-Association of Danish Municipalities, http://www.kl.dk (07.09.2015); E. RollnikSadowska, Model WellBox - możliwości realizacji na polskim rynku pracy (na przyktadzie Klubów 
The municipality plays an important role in the framework composition of a good business environment in the City of Aarhus. The environment influences the growth in the number of jobs and a high rate of employment. An important part of that framework's composition is close cooperation between the city and the companies as recruiters of a qualified labour force, upgrading the skills of both the employed and the unemployed people.

The Jobcenter Aarhus has contact with 3000-5000 companies yearly. In 2014 the number of companies cooperating with the Jobcenter Aarhus reached 4105 and it increased to 5294 in 2015. Annually more than 12000 internship jobs or subsidized jobs are instituted by companies ${ }^{16}$. The companies may be private or public.

Three strategic focus areas secure a strong partnership between the private sector and public employment services (PES). These include a closer location of public employment services to the companies; availability and service of PES; competent and business-oriented jobcenter staff.

Six overall goals have been identified for the collaboration with the companies, which should be reached during $2016^{17}$. They include a high level of satisfaction for the companies; utmost contact with the 8460 work places in local companies with more than one employee; a high degree of availability and high level of information; effective job creation; recruitment partnerships for the companies; the Jobcenter being an effective partner in efforts to keep people on sickness leave in their jobs.

From autumn 2013, the Employment Department at the Aarhus Jobcenter has worked on the implementation of the above strategy at all levels within the organization and in the collaboration with their stakeholders. To secure a successful implementation of that collaboration strategy it is of crucial importance that every social partner takes responsibility for their actions. Moreover, the realization of the strategy should be carried out in close cooperation with the stakeholders; there needs to be full managerial back-up at all levels; management and employees acting as the whole organization should be engaged in the process; exchange of knowledge and experience should take place organization-wide; and that change occurs within a flexible process, to be adjusted when and if required during implementation.

The effectiveness of company collaboration with Danish jobcentres has been monitored by the Danish Agency for Labour Market and Recruitment

Integracji Spotecznej w Eapach i Zabtudowie), "Problemy Polityki Społecznej. Studia i Dyskusje", No. 26/2014, pp. 155-167.

16 Jobcenter Aarhus own statistics 2013.

17 Employment Department of the City of Aarhus, Strategy Paper, Aarhus 2013. 
twice annually since 2013. In 2015 in Jobcenter Aarhus there was invested 12 million DKK in 22 new business consultants. Thanks to their work and increasing the number of activated in private companies with a total of 1100 persons, there was shorten the length of unemployment for each vacant by about $1 \frac{1}{2}$ months. It created the savings of 16 million $\mathrm{DKK}^{18}$.

\section{RECCOMMENDATIONS FOR POLISH LABOUR MARKET INSTITUTIONS}

The flexicurity model is recommended to be implemented in EU countries by the European Commission and it is seen as a crucial element of the European Employment Strategy ${ }^{19}$. It is considered as an answer to the dilemma of how to maintain and improve competitiveness whilst preserving the European social model ${ }^{20}$.

However, some serious obstacles are expected to be encountered in terms of implementing the Danish model in some European countries. It concerns in particular countries like Poland with economies in transition, where a high level of economic growth is necessary in order to reduce unemployment. A major limitation in the implementation of flexicurity appears to be ensuring security, a significant component of the model in the area of social benefits. Poland, with a large budget deficit and high public debt revolving around constitutional restrictions has limited capabilities in terms of financing social benefits. In 2012, expenditures in labour market policies reached $0.767 \%$ GDP in Poland, a GDP that is almost five times less than that of Denmark ${ }^{21}$.

But even though all the Danish patterns seem to meet implementation obstacles in Poland, it is worth analyzing separate solutions, which can be tested under Polish conditions. One would be the above presented cooperation model between private companies and public employment services,

${ }^{18}$ Jobcenter Aarhus own statistics 2016.

19 European Commision, Flexicurity, http://ec.europa.eu/social/main.jsp?catId=102 (30.09.2015).

${ }^{20}$ Alphametrics Ltd., Flexicurity: Indicators on the coverage of certain social protection benefits for persons in flexible employment in the European Union, Royston 2009, p. 3.

${ }^{21}$ In 2012 the difference was higher in the area of passive measures $(0.323 \%$ GDP for Poland and 1.701\% GDP for Denmark) rather than for activation measures $(0.364 \%$ GDP for Poland and $1.459 \%$ GDP for Denmark). The highest loophole exists in the category of financing the public employment service. In Poland only $0.080 \%$ of GDP was spent in comparison to $0.516 \%$ GDP in Denmark (Eurostat, Database, http://ec.europa.eu/eurostat/data/database (14.09.2015)). 
which has been successful in Aarhus. This is of particular import as the efficiency of Polish employment services in the area of gaining employability is very low. Studies carried out in 2006-2007 show that only 48\% of the unemployed received a job offer through one of the District Labour Offices in Poland ${ }^{22}$. The reasons for the low efficiency of those institutions can be attributed to a number of factors (both external and internal). The main external factors are the lack of adequate information that the PES have about labour demand ${ }^{23}$, and unattractive working conditions for the unemployed, or rather potential employees ${ }^{24}$. The internal factors are connected with personality traits and attitudes of the unemployed themselves ${ }^{25}$.

The Danish Collaboration Model shows that placing and training unemployed people within companies is an effective way of vocational training. It allows people to gain a better understanding of the structure, business model and logic of a company. At the same time, it supplies businesses with employees with the particular skills and qualities they need, which might not be available on the external job market. Public Employment Services (PES) benefit from this type of cooperation by gaining knowledge of current labour market demands and tendencies, thus reducing mismatches between the skills that workers have and those that the labour market needs.

\section{CONCLUSIONS}

The role that private companies in the Danish labour active policy play is crucial as their active participation assures a realization of one of the most effective ALMPs, which is private on the job training programs in private companies. In order to realize those programs it is necessary to maintain good relations with representatives of the private sector and ensure their engagement in public policy. This is why Danish public employment services are focused on the development of cooperation hand in hand with the demands on the labour market.

${ }^{22}$ I. Wójcicka, K. Sztandar-Sztanderska, M. Zielińska, Klienci powiatowych urzędów pracy, [in:] Ministerstwo Pracy i Polityki Społecznej, Analiza funkcjonowania urzędów pracy po ich wtaczeniu do administracji samorzqdowej, Warszawa 2008, pp. 47-48.

${ }^{23}$ This is mainly caused by too extensive and bureaucratic procedures for matching the demand by employers for employees with appropriate qualifications and skills.

${ }^{24}$ This mainly concerns the ratio of potential salaries to received benefits.

${ }^{25}$ I. Kukulak-Dolata, Instytucje rynku pracy, [in:] E. Kryńska (ed.), Flexicurity w Polsce. Diagnoza i rekomendacje, Ministerstwo Pracy i Polityki Społecznej, Warszawa 2009, pp. 61-62. 
It goes without saying that the implementation of the Danish cooperation model requires the pro-active attitude of PES personnel and structured follow-up procedures, which would allow the maintenance of constant contact and close communication with companies. It could be argued that Polish employment services lack resources and that they suffer from chronic understaffing, and that in addition a large number of available personnel work on backoffice administration and those in front-line placement functions are burdened with red tape and bureaucracy ${ }^{26}$. Perhaps disconnecting entitlement to health insurance from unemployment registration would help solve or minimize this problem. Another area for improvement could be a better coordination of the PES system and a more efficient exchange of information.

\section{BIBLIOGRAPHY}

Alphametrics Ltd., Flexicurity: Indicators on the coverage of certain social protection benefits for persons in flexible employment in the European Union, Royston 2009.

Andersen T.M., Svarer M., Flexicurity Labour Market Performance in Denmark, “CESifo Economic Studies", Vol. 53, No. 3/2007, http://dx.doi.org/10.1093/cesifo/ifm015.

Employment Department of the City of Aarhus, Strategy Paper, Aarhus 2013.

European Commision, Flexicurity, http://ec.europa.eu/social/main.jsp?catId=102 (30.09.2015).

Eurostat, Database, http://ec.europa.eu/eurostat/data/database (14.09.2015).

Jespersen S.T., Munch J.R., Skipper L., Costs and benefits of Danish active labour market programmes, "Labour Economics", Vol. 15, No. 5/2008, http://dx.doi. org/10.1016/j.labeco.2007.07.005.

Kalužná D., Main Features of the Public Employment Service in Poland, "OECD Social, Employment and Migration Working Papers", No. 80/2009, http://dx.doi. org/10.1787/225485542035.

KL-Association of Danish Municipalities, http://www.kl.dk (07.09.2015).

Kukulak-Dolata I., Instytucje rynku pracy, [in:] E. Kryńska (ed.), Flexicurity w Polsce. Diagnoza i rekomendacje, Ministerstwo Pracy i Polityki Społecznej, Warszawa 2009.

Larsen F., The Importance of Institutional Regimes for Active Labour Market Policies: The Case of Denmark, "European Journal of Social Security", Vol. 6, No. 2/2004.

${ }^{26}$ D. Kalužná, Main Features of the Public Employment Service in Poland, "OECD Social, Employment and Migration Working Papers”, No. 80/2009. 
Madsen K., The Danish model of "Alexicurity" - a paradise with some snakes, [in:] H. Sarfati, G. Bonoli (eds.), Labour market and social protection reforms in international perspective. Parallel or converging tracks?, Ashgate/ISSA, Aldershot 2002.

Ochel W., The Political Economy of Two-Tier Reforms of Employment Protection in Europe, "CESifo Working Paper", No. 2461/2008.

Origo F., Pagani L., Flexicurity and job satisfaction in Europe: The importance of perceived and actual job stability for well-being at work, "Labour Economics", Vol. 16, No. 5/2009, http://dx.doi.org/10.1016/j.labeco.2009.02.003.

Rollnik-Sadowska E., Model WellBox - możliwości realizacji na polskim rynku pracy (na przyktadzie Klubów Integracji Spotecznej w Eapach i Zabtudowie), "Problemy Polityki Społecznej. Studia i Dyskusje”, No. 26/2014.

Rollnik-Sadowska E., System welfare state w Danii - gtówne zatożenia, "Ekonomia i Zarządzanie", Vol. 5, No. 2/2013, http://dx.doi.org/10.12846/j.em.2013.02.01.

Rollnik-Sadowska E., Transformation of European Labour Market Policy Models Exemplified by Denmark, Germany and The United Kingdom, "Optimum. Studia Ekonomiczne”, No.5(71)/2014, http://dx.doi.org/10.15290/ose.2014.05.71.04.

Rosholm M., Svarer M., Overordnede effekter af aktiv arbejdsmarkedspolitik, http:// star.dk (09.04.2016)

Salverda W., Checchi D., Chapter 18 - Labor Market Institutions and the Dispersion of Wage Earnings, "Handbook of Income Distribution", Vol. 2/2015, http://dx.doi. org/10.1016/b978-0-444-59429-7.00019-4.

Wójcicka I., Sztandar-Sztanderska K., Zielińska M., Klienci powiatowych urzędów pracy, [in:] Ministerstwo Pracy i Polityki Społecznej, Analiza funkcjonowania urzedów pracy po ich wtaczeniu do administracji samorzqdowej, Warszawa 2008. 